\title{
Composition of organo-mineral complexes migrating in soddy-podzolic soil (Umbric AlbeluvisolsAbruptic)
}

\author{
OlgaPavlova $^{1}$, AndreyLitvinovich $^{1}$, AntonLavrishchev $^{2}$, Aleksandr Belimov $^{3}$, Elmira Saljnikov $^{4 *}$ \\ ${ }^{1}$ Agrophysical Research Institute, Grazhdanskiystr 14, 195220 St. Petersburg, Russia, \\ ${ }^{2}$ St. Petersburg State Agrarian University, Peterburgsoye ave 2, 196601 St. Petersburg, Pushkin, Russia, \\ ${ }^{3}$ Russian Research Institute for Agricultural Microbiology, Podbelsky str 3, 196608 St. Petersburg, Pushkin, \\ Russia \\ ${ }^{4}$ Soil Science Institute, Teodora Drajzera 7, 11000 Belgrade, Serbia \\ *Corresponding author: Saljnikov Elmira, soils.saljnikov@gmail.com
}

\begin{abstract}
In laboratory column experiments carried out on soddy-podzolic soil reclaimed by industry wastes, the composition of organo-mineral complexes (OMC) migrating during the washing was studied. Carbon from OMC precipitated at $\mathrm{pH} 13$, and ranged from 5.5 to 5.7\%, regardless of the particlesizes of applied ameliorant. The optical density $\left(\mathrm{E}_{\mathrm{c}} \mathrm{g} \mathrm{ml^{-1 }}\right)$ of $\mathrm{OMC}$ solution was 2.7 to 3.1, which is within the range typical forfulvic acids. The total amount of $\mathrm{Ca}, \mathrm{Mg}$, Sr washed out from the OMC depended on the size of the ameliorant particles, as well as the content and ratio of alkaline earth metals in it. The smaller the particle size was, the migration losses of $\mathrm{Ca}, \mathrm{Mg}, \mathrm{Sr}$ were higher. The presence of significant amounts of $\mathrm{Mg}$ in the ameliorant enhances unproductive loss of the bases. According to the ability to migrate in the $\mathrm{OMC}$, the studied elements can be arranged in the following descending order: $\mathrm{Mg}>\mathrm{Ca}>$ Sr. Unexpectedly new finding was that not all organic substances migrating in the profile of reclaimed soddy-podzolic soils can precipitate under the conditions of a strongly alkaline reaction of the medium.
\end{abstract}

Keywords: chalk; organo-mineral complex; migration; alkaline earth metals

\section{INTRODUCTION}

Labile humus compounds constitute the closest reserve of nutrient elements for plants and microorganisms. In the stable pool, for a certain period, the circulation of carbon and other chemical elements is inhibited by accumulation of relatively stable organic and organomineral products (Funakawa et al., 2007). 
Water-soluble organic matter (WSOM) is an integral part of the labile humus. In humus, WSOM is presented by only 0.05 to $1 \%$ (Kalbitz and Kaiser, 2008), what is associated with its increased migration ability and mobility. WSOM have a high reactive and complexion ability, therefore it participates vigorously in the processes of mineral weathering (Kögel-Knabner et al., 2008; Kosanin and Knezevic, 2010; McCauley et al., 2017) and plays a great role in the transport of plant nutrients $(\mathrm{Ca}, \mathrm{Mg})$.

Alkaline earth metals ( $\mathrm{Ca}, \mathrm{Mg}, \mathrm{Sr}$ ) actively migrate in the profile of soddy-podzolic soils, of which $\mathrm{Ca}$ has the greatest mobility. Average annual losses of $\mathrm{CaCO}_{3}$ from arable soils range from 300 to $400 \mathrm{~kg} \mathrm{ha}^{-1}$ (Zelenov et al., 2010), the intensity of Mg migration is lower (12-42 $\mathrm{kg} \mathrm{ha}^{-1}$ per year) (Mazaeva, 1977), and the lowest migration ability has stable $\mathrm{Sr}$ (1.6 $\mathrm{kg} \mathrm{ha}^{-1}$ per year) (Litvinovich et al., 2008; Litvinovich et al., 1999; Salaev and Litvinovich et al., 2017).

For a suitable study of humic materials, good characterization must be achieved for the different fractions to facilitate their behaviour under given conditions. In this paper, the same humic fractions were investigated for their optical densities in an alkaline solution by visible spectroscopy for characterization of humic materials migrating with soil OMC.

The lime fertilizers from industrial waste have different characteristicsand rate of dissolution in soil (Litvinovich and Nebolsina, 2012). The influence of such materials on the components of soil humus often remains unclear. Therefore, the purpose of the present research is to study the composition of organo-mineral complexes leached from soddypodzolic soils reclaimed by industrial wastes in the model experiments on columns.

The research was aimed to establish the carbon content in water-soluble OM, washed out from meliorated soddy-podzolic soils; to measure the optical density of OM removed from the soil because of wetting; determine the content of $\mathrm{Ca}, \mathrm{Mg}$ and $\mathrm{Sr}$, migrating in the composition of WSOM

\section{MATERIALS AND METHODS}

Two laboratory experiments on the columns were laid out: experiment No. 1 and experiment No. 2. Soil samples for the experiment No. 1were taken from the microfield plots, and for the experiment No. 2 from vegetative pot experiments. 


\section{Experiment No. 1.}

Soil samples were taken after a year from liming from the microfield experiment with size of plot $1 \mathrm{~m}^{2}$. The experiment was laid in 2015 with the aim of establishing ameliorative properties of dolomite dropout fractions of less than $0.25 ; 5-7$ and 7-10 $\mathrm{mm}$ and mixtures of fractions $(<0.25,0.25-1,1-3,3-5,5-7,7-10$ and 10-20 mm) used for road construction. Each treatment was replicated 4 times. For studying the effect of the treatments on crop peas (Pisum sativum L.) was cultivated; fertilizer (NPK - 16:16:16) was applied at the rate of 60 $\mathrm{gm}^{-2}$. The scheme of the experiment is presented in Table 1. The dolomite composition was: $\mathrm{CaCO}_{3}$ content was $46.1 \%$; $\mathrm{MgCO}_{3}-38.4 \%$; $\mathrm{Sr}-160 \mathrm{mg} \mathrm{kg}{ }^{-1}$ dropout.

Soddy-podzolic light loamy soil with the following physicochemical parameters was used: $\mathrm{pH}_{\mathrm{KCl}}-4.6$; $\mathrm{Ha}-4.9 \mathrm{mmol}(\mathrm{eq}) 100^{-1} \mathrm{~g}$ of soil; humus $-2.18 \%$; the content of fractions $<0.01 \mathrm{~mm}-21.4 \%$. The dolomite crumb was used in an amount corresponding to the full dose of hydrolytic acidity (1 Ha)calculated as: CaCO3, $\frac{t}{h a}=\frac{H a * 10 * 50 * 3000000}{10^{9}}=H a * 1.5$ ), where $\mathrm{Ha}$ is a hydrolytic acidity, mmol(eq.) $100^{-1} \mathrm{~g}$ soil; 10 is conversion into mmol(eq.) $\mathrm{kg}^{-}$ ; 50 is the amount of $\mathrm{CaCO}_{3}$ required to neutralize $1 \mathrm{mmol}$ (eq) of $\mathrm{H}^{+}$, mg; 3000000 - mass of arable layer per 1 hectare, $\mathrm{kg} ; 10^{9}$ - conversion from $\mathrm{mg} \mathrm{ha}^{-1}$ into $\mathrm{tha}^{-1}$ ).

\section{Experiment No. 2.}

The composition of organo-mineral complexes (OMC) migrating from acidic soddy-podzolic soil, treated by a strontium-containing ameliorant, in an amount corresponding to 2.5 doses calculated according to hydrolytic acidity (Ha) was determined. Soil samples were taken from the pot experiment carried out to establish the translocation of strontium to plants from various biological families 5 years after liming, when the ameliorant completely reacted with soil (Lavrischev, 2016). Crop rotation was: spring rape (Brassica napusL.), vetch (Vicia sativa L.), barley (Hordeum Sativum L.), spring rapeseed, spring rape. Plants were fertilized annually with NPK $(16: 16: 16)$ in a dose of $0.2 \mathrm{~g} \mathrm{~kg}^{-1}$ soil. Conversion chalk (CC) (size <0.25 $\mathrm{mm}$ ), a by-product of the treatment of phosphate raw materials was used as an ameliorant, which contained $\mathrm{CaCO}_{3}-90 \%, \mathrm{Mg}-0.0015 \%$ and $\mathrm{Sr}-1.5 \%$. 
Table 1 The composition of organo-mineral complexes washed out of meliorated soddy-podzolic soils

\begin{tabular}{|c|c|c|c|c|c|c|}
\hline \multirow{2}{*}{ Treatments } & \multirow{2}{*}{$\mathrm{C}_{\mathrm{tot}}, \%$} & \multirow{2}{*}{$\mathrm{E}_{\mathrm{c}} \mathrm{mgml}^{-1}$} & \multicolumn{4}{|c|}{ Content of metals, $\mathrm{gkg}^{-1}$} \\
\hline & & & $\mathrm{Ca}$ & $\mathrm{Mg}$ & $\mathrm{Sr}$ & $\Sigma$ \\
\hline \multicolumn{7}{|c|}{ Experiment No.1 (dolomite crumb) } \\
\hline $\mathrm{NPK}+$ dolomite $<0,25 \mathrm{~mm}$ at $1 \mathrm{Ha}^{\S}$ & $5.6 a^{*}$ & $3.1 \mathrm{a}$ & $123.0 \mathrm{a}$ & $196.1 \mathrm{a}$ & $0.323 \mathrm{a}$ & 319.35 \\
\hline $\mathrm{NPK}+$ dolomite $5-7 \mathrm{~mm}$ at $1 \mathrm{Ha}$ & $5.7 \mathrm{a}$ & $2.7 \mathrm{a}$ & $145.0 \mathrm{a}$ & $120.7 b$ & $0.670 \mathrm{~b}$ & 266.49 \\
\hline $\mathrm{NPK}+$ dolomite $7-10 \mathrm{~mm}$ at $1 \mathrm{Ha}$ & $5.6 \mathrm{a}$ & $2.9 \mathrm{a}$ & $685.0 \mathrm{~b}$ & $110.2 b$ & $0.368 \mathrm{a}$ & 179.05 \\
\hline $\begin{array}{l}\text { NPK }+ \text { mixture of dolomite fractions at } \\
1 \mathrm{Ha}\end{array}$ & $5.5 \mathrm{a}$ & $2.8 \mathrm{a}$ & $511.7 \mathrm{~b}$ & $139.3 b$ & $0.231 \mathrm{a}$ & 190.71 \\
\hline $\mathrm{LSD}_{05}$ & - & - & 120.5 & 2.656 & 0.0126 & - \\
\hline \multicolumn{7}{|c|}{ Experiment No. 2 (conversion chalk) } \\
\hline $\mathrm{NPK}+\mathrm{CC}^{\S \S}$ по $2,5 \mathrm{Ha}$ & $5.5 \mathrm{a}$ & $3.0 \mathrm{a}$ & $117.5 \mathrm{a}$ & $132.92 b$ & $3.050 \mathrm{c}$ & 133.83 \\
\hline
\end{tabular}

Acid soddy-podzolic soils were characterized with the parameters: $\mathrm{pH}_{\mathrm{KCl}}-4.1 ; \mathrm{Ha}-5.4$ mmol (eq) $100^{-1} \mathrm{~g}$ of soil; humus $-3.02 \%$, content of particles with a size $<0.01 \mathrm{~mm}-18.6 \%$.

\section{Column test}

In both experiments, before being placed on the columns, the samples of reclaimed soils were dried, ground, sieved through a $1 \mathrm{~mm}$ mesh sieve and placed in polyethylene columns with a diameter of $65 \mathrm{~mm}$. The mass of soil in the column was $800 \mathrm{~g}$. The height of the soil layer was $18 \mathrm{~cm}$. The packing density was $1.1 \mathrm{~g} \mathrm{~cm}^{-}{ }^{3}$. Each treatment was set in 6 replications.

The soils in the columns were saturated with deionised water until the first drop of leaching moisture appeared, followed by washing with $400 \mathrm{ml}$ of water and collecting the filtrate in a flask.The $\mathrm{pH}$ of the eluate was adjusted to 13 by adding $0.1 \mathrm{NNaOH}$ until the brown flakes of OMC precipitated, which were separated from the supernatant, dried and analysed for total carbon content, for optical density and presence of alkaline earth metals $\mathrm{Ca}$, $\mathrm{Mg}$ and Sr. In the experiment No. 2, the supernatant solution also was analysed.

\section{Analytical methods}

Determination of carbon in the composition of the sediment and supernatant was carried out according to Tyurin (1951), based on the oxidation of humus with a sulphuric chromium mixture (ratio 1:1). The optical density of OMC was measured at the photo-electrocolorimeter by Plotnikova -Ponomareva (1967) with a blue light filter, previously dissolving the precipitate in $\mathrm{NaOH}$. The wavelength was $430 \mathrm{~nm}$ and the cuvette thickness $1 \mathrm{~cm}$. 
The content of elements $(\mathrm{Ca}, \mathrm{Mg}$ and $\mathrm{Sr})$ in the sediments was determined using an ICPE-9000 emission spectrophotometer (Shimadzu, Japan) according to the manufacturer's method. The samples were ground and burned in a mixture of concentrated $\mathrm{HNO}_{3}$ and $38 \%$ $\mathrm{H}_{2} \mathrm{O}_{2}(1: 1)$ at $70^{\circ} \mathrm{C}$ using a DigiBlock system (LabTech, Italy).

\section{RESULTS AND DISCUSSIONS}

\section{Organo-mineral complex and its optical density}

The content of OMC carbon migrated in the soil meliorated by dolomite (experiment No. 1), varied depending on the treatment from 5.5 to $5.7 \%$ (Table 1). The influence of the dolomite size on the amount of leachable carbon was not revealed.

The optical density $\left(\mathrm{OMC}, \mathrm{E}_{\mathrm{c}} \mathrm{mg} \mathrm{m \textrm {m } ^ { - 1 }}\right.$ ) chemically can be defined as an intensity of staining of alkaline solution of OM per unit of carbon: the darker the solution is, the more it contains carbon. At an equal concentration of $\mathrm{C}$ in the solution, the $\mathrm{E}_{\mathrm{c}} \mathrm{mgml}^{-1}$ value depends on the depth of humification (aromatization) of the humic substances in it.

The values of optical density of the migrating organic substances ranged from 2.7 to 3.1 units i.e. were within the range typical for FA (Bakina, 2012). In the experiment using CC, the amount of $\mathrm{C}$ and optical density were not statistically different from the experiments with dolomite.

In our study, the straw-yellow colour of the solution over the sediment, led us to examine the supernatant. The results showed that the least enriched with carbon was the supernatant from the experiment No. $2\left(75.5 \mathrm{~m} \mathrm{gl}^{-1}\right)$ (Fig. 1). The carbon concentration in the supernatant from the experiment No.1 was for 1.21-2.06, depending of the treatment, times higher than in the experiment No. 2. Consequently, not all organic substances migrating in the profile of reclaimed soddy-podzolic soils can precipitate under the conditions of a strongly alkaline reaction of the medium.

The optical density of organic substances not capable to precipitate in the experiment No. 2 was $\mathrm{E}_{\mathrm{c}} \mathrm{mg} \mathrm{ml}^{-1}=1.2$, which corresponds to the fulvic acids, but much lower than the optical density of alkaline solutions of the OMC precipitating after adjusting the $\mathrm{pH}$ of the solution to 12 . 


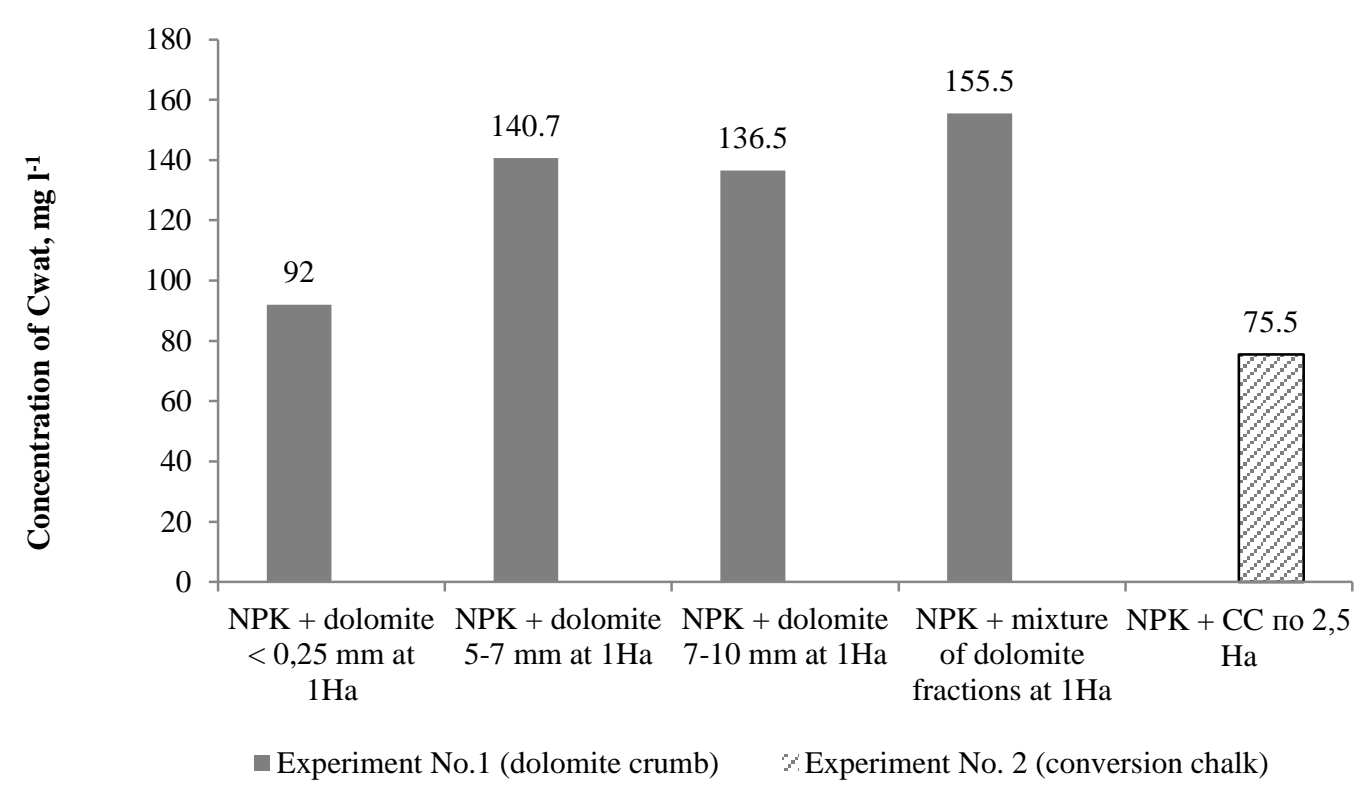

Figure 1 Concentration of water soluble carbon $\left(\mathrm{C}_{\mathrm{wat}}\right)$ in supernatant, $\mathrm{mgl}^{-1},\left(\mathrm{LSD}_{05}=15.5\right)$

Thus, the organo-mineral complexes (OMC), which migrates in the profile of reclaimed soddy-podzolic soils, are heterogeneous in both chemical composition and optical density. Under certain conditions, the most humified part of them can precipitate. Less humified FA, as well as low-molecular organic substances remains in solution. Determination of the amount of FA from those of remaining in solution that are capable of precipitation during alkaline reaction requires special experiments. However, in practical terms in the soil with $\mathrm{pH}$ less than 8.0 FAs cannot be fixed in soils in the form of fulvates of calcium and magnesium and are removed from the soil profile. The OMC capable of precipitation in the case of a strongly alkaline solution contain in their composition significant amounts of alkaline earth metals (Table 1).

\section{Content of calcium and magnesium in OMC}

The highest calcium content in OMC in the Experiment No. 1 was established in the treatment reclaimed by dolomite size of 5-7 $\mathrm{mm}$. In the treatments using dolomite of less than 0.25 and 7-10 $\mathrm{mm}$, the calcium content was lower. The least amount of calcium was washed out from the soil of the treatment limed with a mixture of fractions. Thus, by the amount of leachable calcium in OMC, all studied treatments can be arranged in the following descending order: 5-7 mm>0.25 mm> 7-10 mm> mixture of fractions. 
The leaching of magnesium in the experiment was as follows: the smaller the particle size of dolomite, the higher the magnesium content of the OMC. Thus, the concentration of magnesium in the $\mathrm{OMC}$ of the treatment using the smallest fraction of dolomite was 196. $1 \mathrm{gkg}^{-1}$, and in the treatments using fractions 5-7 and 7-10 mm in size, it decreased for 1.6 and 1.8 times, respectively. The least amount of magnesium leached from the soil OMC was established in the treatment reclaimed by a mixture of fractions.

It is important to emphasize that the content of $\mathrm{Mg}$ in dolomite is less than content of Ca. However, the amount of $\mathrm{Mg}$ washed out from $\mathrm{OMC}$, was 1.6-2.7 times higher than of $\mathrm{Ca}$. Apparently, magnesium has a greater affinity of to the organic matter of the soil. An exception was the treatment using 5-7 $\mathrm{mm}$ size, where the concentration of $\mathrm{Ca}$ was higher than the concentration of $\mathrm{Mg}$.

Even though the dose of CC in the experiment No. 2 was 2.5 times higher than that of dolomite of the same size ( $1^{\text {st }}$ treatment of experiment No. 1$)$, and Ca content was 2 times lower, the amount of $\mathrm{Ca}$ migrating with $\mathrm{OMC}$ was not higher than in the experiment with dolomite (117.5 and $123.0 \mathrm{gkg}^{-1}$, respectively). The concentration of migrating $\mathrm{Mg}$ was much lower than of $\mathrm{Ca}$, due to the extremely low content of this element in the $\mathrm{CC}$.

The dolomite absorbs FA, neutralizing up to $5.4 \%$ of total carbon (Yashin, 1991), then $\mathrm{Ca}$ cations are mobilized into the solution accompanied by formation of WSOM that is characterized with stability and high migration ability. A part of calcium passes into solution and in the form of organo-mineral compounds can migrate in the soil. Yashin (1991) also found that the removal of carbon from the arable horizon reaches $280-310 \mathrm{~kg} \mathrm{ha}^{-1}$ per year, where, fluvic acids tightly bound up to $51.4 \%$ of calcium cations as water-soluble calciumfulvate compounds capable of migration along the soil profile.

Effect of magnesium on soil OM significantly differs from that of calcium. In the lysimetric experiments conducted on strongly acid soddy-podzolic soils, an addition of a large amount of magnesium carbonate resulted in a sharp increase of OM leaching, where a close correlation between the amount of leached $\mathrm{OM}$ and $\mathrm{Mg}$ was observed (Nebolsin and Nebolsina, 2010). 


\section{Content of strontium in OMC}

Litvinovich et al. (1999) found that up to $50 \%$ of soil strontium is associated with humic acids, therefore content of strontium migrating in the composition of OMC are of certain interest.

Our data showed that $\mathrm{Sr}$ was present in OMC of all treatments. In the experiment No. 1, no regularities in leaching, related to the particle size of dolomite could be identified. The sediment of the treatment using a mixture of dolomite fractions was characterized by the least content of strontium. The largest was observed in the treatment ameliorated by 5-7 $\mathrm{mm}$ size dolomite. The difference between the treatments was 2.9 times.

The presence of a significant amount of $\mathrm{Sr}$ in the conversion chalk resulted in increase of $\mathrm{Sr}$ content in OMC migrated in the soil of experiment No. 2, whose concentration was 4.613.1 times higher than in the experiment No. 1.

Noticeably, concentration of the $\mathrm{Mg}$ migrated in the composition of $\mathrm{OMC}$ in the experiment with $\mathrm{CC}$ exceeded the concentration of $\mathrm{Sr}$, although the amount of the latter in the composition of the ameliorant was much larger. Obviously, in the composition of OMC, not only the $\mathrm{Mg}$ of the ameliorant but the $\mathrm{Mg}$ of the soil also migrates.

\section{CONCLUSIONS}

In the experiments carried out on soddy-podzolic soils amended with industrial waste, the composition of OMC migrating from the arable horizon was studied. Regardless of the composition of the ameliorant, the amount of carbon of OMC precipitating in the alkaline solution varied from 5.5 to $5.7 \%$. The optical density index was within the range typical for fulvic acids $\left(\mathrm{Ecmgml}^{-1}=2.7-3.1\right)$.

The total amount of leachable bases was affected by the size and composition of the ameliorant. With smaller dolomite particles and larger area of their interaction with soil, the higher losses of metals was established.

The presence of significant amounts of $\mathrm{Mg}$ in the dolomite increases the total losses of alkaline earth metals due to their migration. By migration ability, studied elements were arranged as follows: $\mathrm{Mg}>\mathrm{Ca}>\mathrm{Sr}$. 
The new finding implies that not all organic substances migrating in the profile of reclaimed soddy-podzolic soils can precipitate under the conditions of a strongly alkaline reaction of the medium.

Acknowledgment: The research was supported by the Russian Science Foundation (Grant No. 14-16-00137).

\section{References}

Bakina LG. 2012: Role of fractions of humic substances in soil-ecological processes. Doctoral thesis, St. Petersburg, Russia, $381 \mathrm{p}$

Funakawa S, Yanai J, Takata Yu, Karbozova-Saljnikov E, KosakiT. 2007: Dynamics of water and soil organic matter under grain farming in Northern Kazakhstan- Toward sustainable land use both from the agronomic andenvironmental viewpoints. In: R. Lal et al., (Eds). Climate Change and Terrestrial Carbon Sequestration in Central Asia. Netherlands, Taylor\&Francis, pp. 279-331

Kalbitz K, Kaiser K. 2008: Contribution of dissolved organic matter to carbon stogare in forest mineral soils. J. Plant Nutr. Soil Sci. 171, 1:52-60

Kosanin O., Knezevic M. 2010: Podzolized acid brown soil. Zemljiste i Biljka (Plant and Soil), ISSN 2560-4279, 59, 1:1-14

Kögel-Knabner I, Guggenberger G, Kleber M, Kandeler E, Kalbitz K, Scheu S, Eusterhues K, Leinweber P. 2008: Organo-mineral associations in temperate soils: Integrating biology, mineralogy, and organic matter chemistry. Z. Pflanzenernähr. Bodenk, 171: 61-82. doi:10.1002/jpln.200700048

Lavrishchev AV. 2016: Studying the behaviour of stable strontium in agroecosystems of the North-West of Russia. Doctoral Thesis, St. Petersburg State Agrarian University, Russia, 272 p.

Litvinovich AV, Pavlova OYu, Yuzmukhametov DN. LavrishchevAV. 2008: The migration capacity of stable strontium in soddy-podzolic soils of the Russian Northwest (Data of simulation experiments). Eurasian Soil Science, 41(5):502-508

Litvinovich AV, Bakina LG, Pavlova OYu, Lavrischev AV. 2017: Stability of organic matter and calcium of calcified soil to the leaching effect of water. Agrochemistry, 3:58-68

Litvinovich AV, Nebolsina ZP. 2012: The duration of action of calcareous ameliorates in soils and the effectiveness of liming. Agrochemistry, 10:79-94 
Litvinovich AV, Pavlova OYu, Lavrischev AV. 1999: About leaching of calcium and strontium from soddy-podzolic sandy loam soil limed by conversion chalk. Agrochemistry, 9:64-67

Mazaeva MM. 1977: About depletion of soddy-podzolic soil by magnesium and the possibility of manifestation of plant defficiency under long-term systematic application of NPK fertilizers. Agrochemistry, 9:97-101

McCauley A, Jones C, Kathrin OR. 2017: Soil pH and Organic Matter. Nutrient ManagementModule No.8. Montana State University, Extension, pp.1-16.

Nebolsin AN. 2010. Agronomical role of humus in agriculture. In: A.N. Nebolsin (Ed)Modern problems and perspectives of liming of acidic soils. St. Petersburg, pp. 819

Nebolsin AN, Nebolsina ZP. 2010. Liming of soils. St. Petersburg, GNU LNIISH, 254 p.

Plotnikova TA, Ponomareva VV. 1967: Simplified version of the method for determination of optical density of humic substances with a single filter, Pochvovedenie, 7:73-85

Salaev IV, Litvinovich AV. 2017: Migration of alkaline-earth metals in liming with dolomite. In: Proceedings of scientific works of the international scientific and practical conference of young scientists: The role of young scientists in solving urgent problems of the agro-industrial complex. Moscow, Russia, 30-31 May 2017, pp. 77-79

Tyurin IV. 1951: To the method of analysis for a comparative study of composition of soil humus. Archives of Dokuchaev Soil Institute, 38:5-21

Yashin IM. 1991: Interaction of iron hydroxide, of humic acids and dolomite with watersoluble organic substances of podzolic soils. News of the Timiryazev Agricultural Academy, 5, 46-61

Zelenov NA, Shilnikov NI, Akanova NI, Shvyrkov DA. 2010: The reserve of chemical ameliorants and their agroecological efficiency. In: A.N. Nebolsin (Ed) Modern problems and perspectives of liming of acidic soils. St. Petersburg, pp. 30-34 


\title{
Sastav organsko-mineralnih kompleksa koji migriraju u zemljištu tipa Umbric Albeluvisols Abruptic
}

\author{
Olga Pavlova ${ }^{1}$, Andrey Litvinovich ${ }^{1}$, Anton Lavrishchev $^{2}$, Aleksandr Belimov $^{3}$, Elmira Saljnikov $^{4 *}$ \\ ${ }^{1}$ Agrophysical Research Institute, Grazhdanskiy str 14, 195220 St. Petersburg, Russia, \\ ${ }^{2}$ St. Petersburg State Agrarian University, Peterburgsoye ave 2, 196601 St. Petersburg, Pushkin, Russia, \\ ${ }^{3}$ Russian Research Institute for Agricultural Microbiology, Podbelsky str 3, 196608 St. Petersburg, Russia \\ ${ }^{4}$ Soil Science Institute, Teodora Drajzera 7, 11000 Belgrade, Serbia \\ *Corresponding author:soils.saljnikov@gmail.com
}

Zemljište tipa Umbric Albeluvisols Abruptic je tretirano industrijskim otpadom u cilju proučavnja sastava organsko mineralnog kompleksa koji migriraju tokom ispiranja. Ogled je sproveden u laboratorijskim uslovima sa kolonama. Taloženje ugljenika iz OMK se dešavalo u izuzetno baznoj sredini pri pH 13 i njegov sadržaj je iznosio od 5.5-5.7\% bez obzira na veličinu čestica primenjenog tretmanskog sredstva. Utvrđena optimalna gustina $\left(\mathrm{E}_{\mathrm{c}} \mathrm{gml}^{-1}\right)$ rastvora je iznosila od 2.7-3.1, što je u karakteristično za opseg fulvo-kiselina. Ukupna isprana količina $\mathrm{Ca}, \mathrm{Mg}$ i $\mathrm{Sr}$ isprana iz $\mathrm{OMK}$ je zavisila od veličine čestica tretmanskog sredstva (ili melioracionog) kao i od sadržaja i odnosa zemnoalkalnih metala u njemu. Smanjenje veličine čestice je dovodilo do većih migracionih gubitka $\mathrm{Ca}, \mathrm{Mg}$, i Sr. Takođe je utvrđeno da povećani sadržaj $\mathrm{Mg}$ u tretmanskom sredstvu je povećavalo gubitak baza iz zemljišta. Prema sposobnosti migracije kod ispitivanih elmenata je utvrđen sledeći redosled: $\mathrm{Mg}>\mathrm{Ca}>\mathrm{Sr}$. Neočekivano je utvrđeno da u izraženo alkalnoj sredini ne dolazi do taloženja svih organskih supstanci u profile zemljišta tipa Umbric Albeluvisols Abruptic.

Ključne reči: kreda; organsko mineralni kompleks; migracija; zemnoalkalni metali 